\title{
Neubenennungen lithostratigraphischer Einheiten in der helvetischen Kreide (Schweizerisches Komitee für Stratigraphie (Swiss Journal of Geosciences, 102/2) Comment on the article by the Schweizerisches Komitee für Stratigraphie (SJG, Vol 102/2) What is in a stratigraphical name?
}

\author{
KARL B. FÖLLMI
}

ABSTRACT

The two newly defined lithostratigraphic units - the Rohrbachstein and Plaine-Morte Beds - within the recently reinstated Grünten Member (former "Upper Orbitolina Beds") embody characteristic lithostratigraphic units, which are well distinguishable in the field. They furthermore bear significant paleoceanographic information in that they document the final drowning

episode of the Schrattenkalk carbonate platform (Rohrbachstein Bed) and overlap with oceanic anoxic event 1a ("Selli event": Plaine-Morte Bed). Their use is in line with a long-standing tradition to name individual phosphate- and glauconite-containing marker beds and is fully justified with respect to the Swiss guidelines of stratigraphical nomenclature (Remane et al. 2005).

\section{Introduction}

Stratigraphers decipher the history of our Earth by carefully reading the preserved sedimentary archives - formation by formation, layer by layer, and in many cases even lamina by lamina. They are the true Sherlock Holmes in the exploration of Earth history, in translating a dull-looking sediment succession into a detailed account of life, climate and environment at the time of deposition. As for each discipline, a series of rules is necessary, which should principally help stratigraphers to guide them in their quest and allow for maximal transparency in stratigraphical deductions.

Here I will show that the names we have proposed for two newly discovered phosphatic and/or glauconitic beds within the Cretaceous Garschella Formation of the Helvetic Alps (Rohrbachstein and Plaine-Morte Beds; Föllmi et al. 2006, 2007; Föllmi \& Gainon 2008) are both essential for a better understanding of its stratigraphy and for the paleoceanographic and paleoenvironmental information contained within this formation, as well as justified by national stratigraphical standards.

\section{History of the stratigraphy of the Garschella Formation}

The Garschella Formation is essentially composed of glauconitic sandstone, marlstone, neritic and hemipelagic carbonate, and phosphorites of Aptian to Cenomanian age. It embodies an overall reduced succession, which rarely attains a thickness of more than several meters to several tens of meters. Its uniqueness lies in the fact that it documents the final drowning phase of the northern Tethyan shallow-water carbonate platform during the Aptian and that it contains highly condensed phosphorite beds, which are equivalent to the numerous basinal oceanic anoxic events, which took place during this period. As such, the Garschella Formation documents an ancient analogue of present-day environmental change characterized by increased nutrient input into the ocean and as a consequence the widespread demise of coral reefs and the development of so-called "dead zones", which are oceanic domains facing severe oxygen depletion.

The unique character of the Garschella Formation was discovered early on in the stratigraphical exploration of the Helvetic thrust-and-fold belt, and excellent and very detailed descriptions were provided by Jacob \& Tobler (1906), Heim (1910-1916, 1919), Ganz (1912), Heim \& Seitz (1934), and Fichter (1934). Heim (1934) defined the concept of sedimentary condensation using the example of the Garschella Formation. These authors proposed a detailed stratigraphical nomenclature, in which each phosphorite bed obtained its proper name based on a locality in which the bed is particularly well exposed (e.g., Luitere Bed, Durschlägi Bed, Plattenwald Bed, Kamm Bed). The phosphorite layers partly

Institut de Géologie et Paléontologie, Université de Lausanne, Anthropole,1015 Lausanne, Switzerland. E-mail: karl.foellmi@unil.ch 
resemble, and in incomplete outcrops, their identification is not always without difficulty, as was demonstrated by the famous dispute between Heim (1910-1916) and Ganz (1912) on the stratigraphical position of the Durschlägi Bed (cf. Föllmi \& Ouwehand 1987). To this comes that individual phosphorite beds of the Garschella Formation have the tendency to bundle in distal directions, such as is the case for the Twäriberg, Durschlägi, Wannenalp and Kamm Beds, which merge into the phosphorite bed of the Plattenwald Bed (cf. Föllmi \& Ouwehand 1987).

In order to describe the stratigraphy and sedimentology of these beds and their tendency to merge in distal directions, each bed has to have a name, and the stratigraphers working on the Garschella Formation in the first part of the $20^{\text {th }}$ century fully recognized this fact. Their names became all the more important since the realization, that these beds are partially the expression of oceanic anoxic events on the northern Tethyan shelf. The Twäriberg Bed and Durschlägi Bed correlate, for instance, well with oceanic anoxic event 1 b (latest Aptian to earliest Albian), and the Wannenalp Bed embodies the equivalent of oceanic anoxic event $1 \mathrm{~d}$.

\section{The case of the Rohrbachstein and Plaine-Morte Beds}

The Lower Aptian sediments of the "Upper Orbitolina Beds", which were recently baptized as Grünten Member (Linder et al. 2006, thereby following an earlier proposal of Heim 1919), form a "missing link" between the Upper Barremian to Lower Aptian platform carbonates of the Urgonian Schrattenkalk Formation and the overlying Garschella Formation. They only rarely outcrop in the Helvetic Alps and occurrences are merely established from Allgäu, Vorarlberg, and central Switzerland (e.g., the areas of the Fronalpstock, Nieder- and Oberbauen, valley of Engelberg, Lake of Sarnen, and the area of Rawil - Col de la Plaine Morte). These sediments did not receive the same attention as the sediments of the widespread Garschella Formation, and detailed stratigraphical analyses were performed only recently (cf. Linder et al. 2006).

The value of the Grünten Member lies in the fact that it documents the drowning of the Schrattenkalk platform in great detail and that it allows for precisions in its dating, which were hitherto not obtained. Linder et al. (2006) showed that because of the presence of phosphorite beds and lateral transition into the condensed phosphorite Luitere Bed, this member is to be included into the Garschella Formation, rather than in the Schrattenkalk Formation, as was formerly the case. In several recent publications, we also described the discovery of two phosphate- and/or glauconite-containing layers within the Grünten Member, which both have important implications for our understanding of the general stratigraphy and sedimentology of this member, and for their paleoceanographic interpretation (Föllmi et al. 2006, 2007; Föllmi \& Gainon 2008; Föllmi 2008).

\section{The Rohrbachstein Bed}

The first layer - the Rohrbachstein Bed - marks the boundary between the top of the Urgonian Schrattenkalk Formation and the overlying Grünten Member. The top of the Schrattenkalk Formation is developed as a firm- or hardground, which is partly eroded. In Allgäu, the Rohrbachstein Bed is composed of a $10-\mathrm{cm}$ thick coarsely-grained glauconitic sandstone rich in pyrite. In the Oberbauen region, the Rohrbachstein Bed attains a maximal thickness of around two meters and consists of a coarsely-grained crinoidal limestone containing various amounts of quartz sand, glauconite, and reworked extraclasts from the underlying Schrattenkalk Formation ("Basisbreccie" of Fichter 1934). Belemnites, oysters, and rare ammonites occur within this bed (Fichter 1934; Linder et al.2006). The upper boundary of the Rohrbachstein Bed is defined by a rapid transition into finer-grained, partly marly crinoidal limestone of the lower Grünten Beds. It is interpreted as a transgressive lag deposit, which is well distinguishable in the field. In the region of the Col de la Plaine Mort, the hardground on top of the Schrattenkalk Formation is covered by phosphatic patches, which are considered as an equivalent of the Rohrbachstein Bed (Föllmi \& Gainon 2008).

The Rohrbachstein Bed is important as it documents the drowning of the Schrattenkalk Formation marked by the installation of a hardground, phosphogenesis and glauconite formation, erosion and sediment reworking, and the importation of detrital quartz. It signals the final disappearance of photozoan carbonate production, and shows that carbonate production came to a complete halt, before it took up again in a heterozoan mode, as documented by the lower Grünten Beds. The presence of belemnites and rare ammonites suggests relative sea-level rise associated with the drowning event and the emplacement of the Rohrbachstein Bed. Its age is near the boundary between the weissi and deshayesi ammonite zones.

The arguments of the stratigraphical committee to refuse the name "Rohrbachstein Bed" are most interestingly different in the English abstract and the German main text. In the English abstract, the committee maintains that the Rohrbachstein Bed represents "only a minor lithologic variation within the Grünten Member". This is wrong for two reasons. First of all, the bed is very well distinguishable by its mineralogical composition and granulometry from the underlying and overlying stratigraphical unities, and secondly, this bed is placed at the base of the Grünten Member and not within. In the German main text, the committee acknowledges instead that the Rohrbachstein Bed is lithologically different (sic), but that this is not a reason to give this unity a name, because "there are dozens of lithologically somewhat different horizons at lithological boundaries and within lithostratigraphic units in the Helvetic unit, which cannot all be named" (translation by the author). This reasoning is not acceptable, in that it not only undermines the quest for the most precise stratigraphical description and interpretation in general, but also questions the earlier ap-

516 K. B. Föllmi 
proaches of such acclaimed stratigraphers as Arnold Heim and Ernst Ganz.

\section{The Plaine-Morte Bed}

In the area of the Col de la Plaine Morte, the Plaine-Morte Bed embodies an approximately 20-cm thick nodular phosphatic layer within the Grünten Member, which is well distinguishable in the field. The Plaine-Morte Bed includes large clasts composed of crinoidal limestone of the lower Grünten Beds, which are peripherically phosphatized and small phosphatic nodules and particles. Sparse ammonites indicate the deshayesi and furcata ammonite zones (Föllmi \& Gainon 2008). In this region, the Plaine-Morte Bed merges laterally with the higher Luitere Bed, and the intervening upper Grünten Beds disappear.

The importance of this bed is that it helps us to explain the older ages shown in distal occurrences of the Luitere Bed in Allgäu and Vorarlberg, where ammonites are present from the deshayesi and furcata ammonite zones (besides younger ammonites indicating the early Late Aptian). These older ages can be explained by the Luitere Bed being merged with the PlaineMorte Bed, in analogy of what is observed in the area of the Col de la Plaine Morte. This merging pattern is well comparable to the merging of different phosphorite beds into one singe bed higher up in the Garschella Formation.

To this comes that with the Plaine-Morte Bed, the imprint of oceanic anoxic event 1a (the so-called "Selli event") has been discovered on the northern Tethyan margin.

In its justification, the Swiss stratigraphical committee maintains that "The term Plaine-Morte Bed for a thin condensed horizon can not be accepted due to the fact that its definition is based mainly on biostratigraphy". This argumentation is incomprehensible, since the bed represents a well-distinguishable phosphatic horizon within the sandy, crinoidal carbonates of the Grünten Member. As such, it is well comparable to other phosphorite beds within the Garschella Formation. In the german text, the committee forwards furthermore the argument that "the merging of the Plaine-Morte Bed with the overlying Luitere Bed has not been well described". This argument does not directly deal with the feasibility of naming this distinct lithological unit, and is furthermore not true, since a detailed description and illustration has been given in Föllmi \& Gainon (2008; figure 14). The final argument that this name is already used for a wildflysch unit is also obsolete, since any field geologist will be able to distinguish between a Plaine-Morte condensed phosphorite bed and a Plaine-Morte wildflysch. Furthermore, the Swiss guidelines for using stratigraphical nomenclature (Remane et al. 2005) do not exclude the use of the same name for entirely unrelated stratigraphical units (though it excludes the use of the same name for a formation and for the members or beds contained therein).

It appears from this that the use of the names "Rohrbachstein Bed" and "Plaine-Morte Bed" is fully compatible with the Swiss guidelines of stratigraphical nomenclature (Remane et al. 2005) and that the arguments of the Swiss stratigraphical committee refuting the use of these names can by no means be maintained.

\section{Outlook}

Juliet asked Romeo: "What's in a name? That which we call a rose by any other name would smell as sweet." (Shakespeare: Romeo and Juliet, II, ii, 1-2). Is this not true as well in stratigraphy? A name is used to identify an individual entity, be it human, a fossil or a rock. In the multitude of lithostratigraphical unities identified on our world, a flexible approach in the use of names should be possible, in order to allow for maximal simplicity and minimal effort. Names are given to lithological units, which are well distinguishable and individualized; a name is all the more justified, if these units have a story to tell, such as is the case with the Rohrbachstein and Plaine-Morte Beds.

Names should serve the purpose of stratigraphy; the inverse would constrain our quest for clarity in lithostratigraphical nomenclature and descriptions, thereby giving justice to Juliet, who exclaimed "Tis but thy name that is my enemy" (Shakespeare: Romeo and Juliet, II, ii, 1-2).

\section{REFERENCES}

Fichter, H.J. 1934: Geologie der Bauen-Brisen-Kette am Vierwaldstättersee und die zyklische Gliederung der Kreide und des Malm der helvetischen Decken. Beiträge zur geologischen Karte der Schweiz NF 69, 129 pp.

Föllmi, K.B. 2008: A synchronous, middle early Aptian age for the demise of the Helvetic Urgonian platform related to the unfolding oceanic anoxic event 1a ("Selli event"). Revue de Paléobiologie 27, 461-468.

Föllmi, K.B. \& Ouwehand, P.J.1987: Garschella-Formation und Götzis-Schichten (Aptian-Coniacian): Neue stratigraphische Daten aus dem Helvetikum der Ostschweiz und des Vorarlbergs. Eclogae geologicae Helvetiae 80,141-191.

Föllmi. K.B., Godet, A., Bodin, S. \& Linder, P. 2006: Interactions between environmental change and shallow-water carbonate build-up along the northern Tethyan margin and their impact on the early Cretaceous carbon-isotope record. Paleoceanography 21, doi:10.1029/2006PA001313.

Föllmi. K.B., Bodin, S. Godet, A., Linder, P. \& van de Schootbrugge, B. 2007: Unlocking paleo-environmental information from Early Cretaceous shelf sediments in the Helveti Alps: Stratigraphy is the key! Swiss Journal of Geosciences 100,349-369.

Föllmi, K.B. \& Gainon, F. 2008: Demise of the northern Tethyan Urgonian carbonate platform and subsequent transition towards pelagic conditions: the sedimentary record of the Col de la Plaine Morte area, central Switzerland. Sedimentary Geology 205, 142-159.

Ganz, E. 1912: Stratigraphie der mittleren Kreide (Gargasien, Albien) der oberen helvetischen Decken in den nördlichen Schweizeralpen. Denkschriften der Schweizerischen Naturforschenden Gesellschaft 47, $148 \mathrm{pp}$.

Heim, A. 1910-1916: Monographie der Churfirsten-Mattstock-Gruppe. Beiträge zur geologischen Karte der Schweiz NF 20/1-3, 573 pp.

Heim, A. 1919: Zur Geologie des Grünten im Allgäu. Vierteljahrschrift der naturforschenden Gesellschaft Zürich 64, 458-486.

Heim, A. 1934: Stratigraphische Kondensation. Eclogae geologicae Helvetiae $27,372-383$.

Heim, A. \& Seitz, O. 1934: Die mittlere Kreide in den helvetischen Alpen von Rheintal und Vorarlberg und das Problem der Kondensation. Denkschriften der Schweizerischen Naturforschenden Gesellschaft 69, 185310.

Jacob, C. \& Tobler, A. 1906: Etude stratigraphique et paléontologique du Gault de la vallée de la Engelberger Aa (Alpes calcaires suisses, environs 
du lac des Quatre Cantons). Mémoires de la Société paléontologique de la Suisse 33, 3-26.

Linder, P., Gigandet, J., Hüsser, J.L., Gainon, F. \& Föllmi, K.B. 2006: The early Aptian Grünten Member: description of a new lithostratigraphic unit of the Helvetic Garschella Formation. Eclogae geologicae Helvetiae 99, 327-341.

Remane, J., Adatte, T., Berger, J.-P., Burkhalter, R., Dall'Agnolo, S.D., Decruez, D., Fischer, H., Funk. H., Furrer, H., Graf, H.-R., Gouffon, Y., Heckendorn,
W. \& Winkler, W. 2005: Guidelines for stratigraphic nomenclature. Eclogae geologicae Helvetiae, 98, 385-405.

Manuscript received September 10, 2009

Revision accepted November 30, 2009

Editorial Handling: S. Bucher 